\title{
PHYSICOCHEMICAL PARAMETERS AND NUTRIENTS VARIATIONS OF STREAMS AND RIVERS IN ABAKALIKI, EBONYI STATE, NIGERIA
}

\author{
OMAKA O.N. ${ }^{1,2, *}$ \\ NWABUE F.I. ${ }^{1}$ \\ ITUMOH E.J. ${ }^{1}$ \\ OROKE E.C. ${ }^{1}$ \\ IGWE D.O. ${ }^{1}$
}

\author{
${ }^{1}$ Department of Industrial Chemistry \\ Ebonyi State University \\ Abakaliki, Ebonyi State, Nigeria \\ ${ }^{2}$ Department of Chemistry/Biochemistry/Molecular Biology \\ Federal University Ndufu, Alike Ikwo, P. M. B. 1010 \\ Abakaliki, Ebonyi State, Nigeria
}

Received: 27/09/2013

Accepted: 21/05/2013

*to whom all correspondence should be addressed: e-mail: omakand@yahoo.co.uk

\begin{abstract}
Physicochemical parameters and nutrient loads of major rivers and streams in Abakaliki, Ebonyi State were studied for a period of seven (7) months from May to November, 2011. Regular and constant monitoring of water bodies is vital to ensure that water quality characteristics are maintained. The results obtained showed; temperature $\left(28.60-30.00^{\circ} \mathrm{C}\right), \mathrm{pH}(6.80-7.93), \mathrm{DO}(1.40-$ $\left.3.53 \mathrm{mg} \mathrm{I}^{-1}\right)$, turbidity $(41.33-97.67 \mathrm{NTU})$, conductivity $\left(19.00-613.30 \mu \mathrm{S} \mathrm{cm}^{-1}\right)$, total acidity $(9.17-$ $\left.17.23 \mathrm{mg} \mathrm{l}^{-1}\right)$, total alkalinity $\left(6.43-10.97 \mathrm{mg} \mathrm{l}^{-1}\right)$, BOD $\left(1.20-7.03 \mathrm{mg} \mathrm{l}^{-1}\right)$, COD (16.200-53.533 $\left.\mathrm{mg} \mathrm{l}^{-1}\right)$, Phosphate $\left(0.11-1.17 \mathrm{mg} \mathrm{l}^{-1}\right)$ and Nitrate $\left(0.12-1.45 \mathrm{mg} \mathrm{I}^{-1}\right)$ ranges respectively. The turbidity and BOD were well above the prescribed standards. The results suggest that refuse disposal, fertilizer use, and natural phenomena e.g. soil erosion; flooding, etc. may have contributed in various ways to the impairment of the water quality of the studied sites. Although the results do not indicate adverse pollution status of any of the sites, they provided the need for further investigations and monitoring.
\end{abstract}

KEYWORDS: Physicochemical Parameters, Nutrients, Water Quality, Abakaliki.

\section{INTRODUCTION}

The water quality of rivers, streams and lakes changes with the seasons and this has profound influence on the population density of aquatic plants and animals (Lawson, 2011; Adeyemo et al., 2008). The geography and the topography of an area also affect the water quality of that area. Anthropogenic activities, natural processes e.g. erosion, weathering, geochemical and geological characteristics of the environment as well as the ever increasing population of the world have kept changes in natural water bodies constant (Arain et al., 2008; Adefemi and Awokunmi, 2010; Nduka, 2008; Bellingham, 2012). As a result, physical, chemical and biological parameters that influence water quality keep changing. Therefore, regular quality monitoring of water bodies to ascertain these changes from time to time is necessary (Arain et al., 2008). The reasons for this are enormous. Water is an essential component for survival of life on earth, and the minerals it contains are important for humans as well as for earth and aquatic life (Arain et al., 2008; Lawson, 2011; Murhekar, 2011). Monitoring of water quality will ensure protection of public health (WHO, 2011), since about $90 \%$ of water supply globally comes from large water bodies.

Important physical and chemical parameters that affect the natural water quality are temperature, $\mathrm{pH}$, Turbidity, Dissolved Oxygen (DO), Biochemical Oxygen Demand (BOD), Chemical Oxygen Demand (COD), alkalinity, nutrients (Nitrate-N, Phosphate-P), etc. (Lawson, 2011; Nduka et al., 2008). These parameters are limiting factors for the survival of aquatic organisms (flora and fauna) (Lawson, 2011). 
Turbid water caused by suspended and colloidal matter such as clay may be the result of soil erosion, urban runoff, algal blooms, and bottom sediment disturbances, silt, organic and inorganic matter, and microscopic organisms (Murhekar, 2011) and also boat traffic and abundant bottom feeding fish.

Alkalinity due to the presence of bicarbonate, carbonate and hydroxides of calcium, sodium and potassium (Murhekar, 2011; Lawson, 2011) is vital in neutralizing the acidity of water which increases with dissolved carbon dioxide (Lawson, 2011).

Temperature is one of the limiting factors in the aquatic environment (Lawson, 2011; Murhekar, 2011). Aquatic animals (e.g. stream insects, trout, and salmon) are sensitive to changes in water temperature and require a certain temperature range to survive and thrive. If water temperature is outside the range for a long time, organisms can be stressed and die. Temperature also affects the amount of oxygen water can hold. Cold water holds more oxygen than warm water, and all aquatic animals need oxygen to survive. Temperature also affects the rate of photosynthesis by aquatic plants, reproduction and metabolic activities (Lawson, 2011) and the sensitivity of organisms to toxic wastes, parasites and diseases. Warm water discharged from factories (Murhekar, 2011), the removal of trees and vegetation that shade streams, and water that runs off city streets can cause temperature changes that may threaten the balance of aquatic systems. Water temperatures usually show a characteristic annual cycle, with higher values during the (dry season) summer and lower values in the (rainy season) winter (Arain et al., 2008).

Dissolved Oxygen (DO) is important to health of aquatic ecosystems. All aquatic animals need oxygen to survive. Natural waters with consistently high dissolved oxygen levels are most likely healthy and stable and are capable of supporting a diversity of aquatic organisms. Cold water can hold more dissolved oxygen than warm water. High levels of bacteria or large amounts of rotting plants decreases DO percentage saturation resulting to large fluctuations in dissolved oxygen levels throughout the day which can affect the ability of plants and animals to thrive.

Most aquatic animals prefer a pH range of 6.5 - 8.0. Lawson, (2011) reported that aquatic shrimps and crabs require optimum $\mathrm{pH}$ range of $6.8-8.7$ for maximum growth and reproduction. At adverse $\mathrm{pH}$ level, they may die, stop reproducing, or move away from the region. Low $\mathrm{pH}$ can also allow toxic compounds to become more available to aquatic plants and animals. This can produce conditions that hurt aquatic life. $\mathrm{pH}$ can be affected by atmospheric deposition, wastewater discharges, drainage from mines, and the type of rock naturally found in the area. According to WHO, (2011), there is no health-based guideline value for $\mathrm{pH}$, although $6.5-8.5$ is proposed for drinking water.

Nutrient enrichment of surface waters has generated concern due to the ecological impacts on both freshwater and estuarine systems (Prior and Johnes, 2002). Nitrogen (N) and phosphorus (P) species are notable characteristic pollutants for eutrophication of natural waters (Prior and Johnes, 2002; Withers and Lord, 2002; Halliwell et al., 1996; Omaka et al., 2007; Zanin et al., 1998). High concentration of nitrate in drinking water sources can be fatal to humans and animals (Monteiro et al., 2003; Zatar et al., 1999), while elevated concentration of phosphorus may result in fouling of natural water and production of toxic cyanobacteria (Omaka, 2007).

The objective of this study was to investigate the physicochemical parameters and nitrogen- $\mathrm{N}$ and phosphorus-P loads and hence the water quality status of Rivers and Streams within Abakaliki, Ebonyi State in both the dry and rainy seasons and pinpoint areas where further studies were necessary.

\section{MATERIALS AND METHODS \\ Study areas}

Ebonyi State is an agrarian State located in the South Eastern Benue Trough of Nigeria (Omaka et al., 2011; Collins-Longman, 1981) (see Fig. 1). The main study area falls within the climatic region of South Eastern Nigeria where the rainy season spans from April to October and the dry season from October to April (Ezeh and Ugwu, 2007; Omaka et al., 2011). The average annual rainfall of the study area is about $1500 \mathrm{~mm}$ with actual surface temperature (seasonal temperature) of between 24-36 ${ }^{\circ} \mathrm{C}$ during dry season and about $18{ }^{\circ} \mathrm{C}$ during the rainy season (Ezeh and Ugwu, 2007; Collins-Longman, 1981). 
The study area is of high leached red soils of tropical forest areas with the vegetation dominated by grasses, shrubs and trees e.g. palm trees, coconut, mango, and orange trees). The State is majorly drained by the Ebonyi R. and Akpoha R., with minor tributaries, streams and ponds scattered around the area (Omaka et al., 2011).

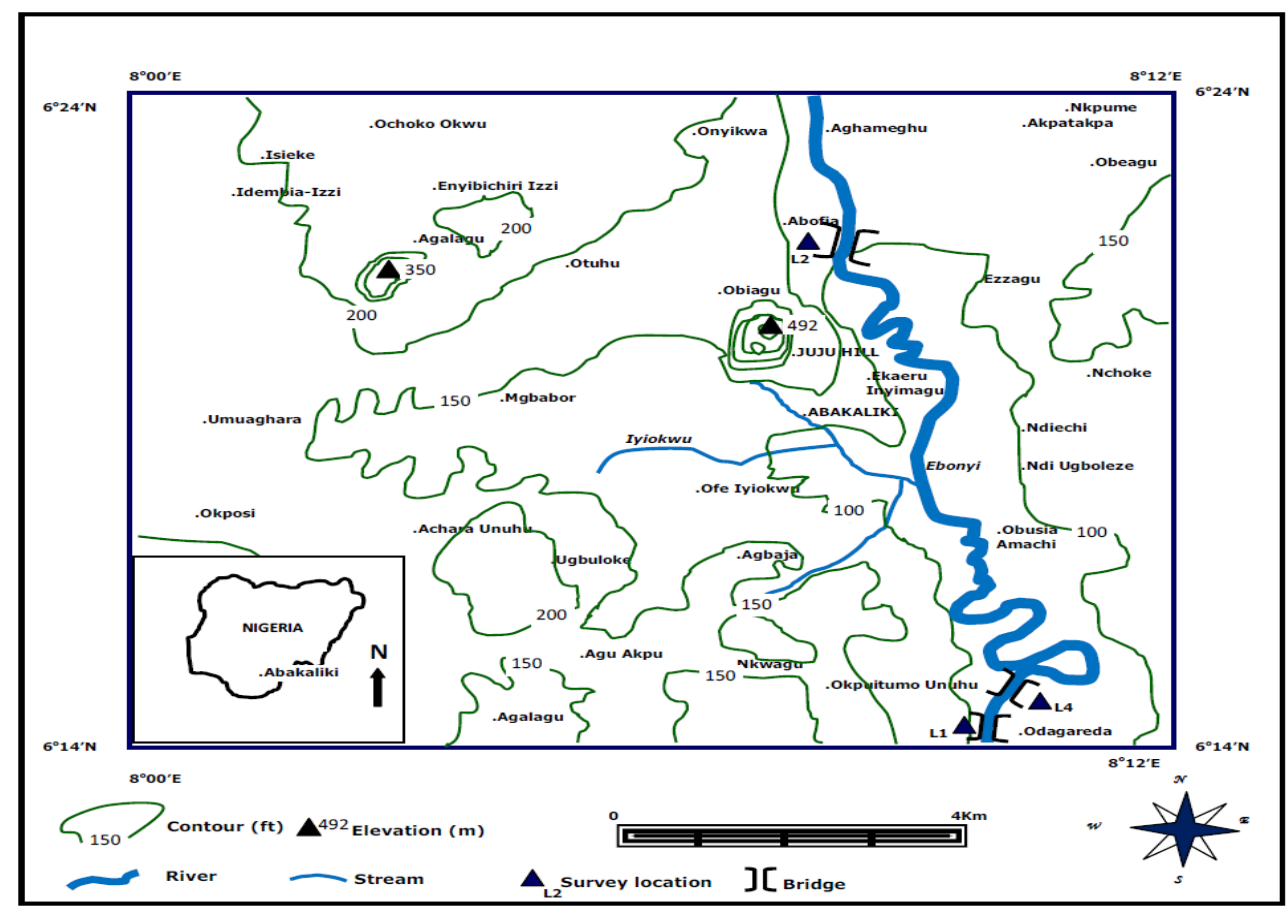

Figure 1. A map showing the sampling sites around Abakaliki Metropolis, Ebonyi State

\section{Sampling and Sampling Procedures}

In order to avoid contamination, all glasswares, high-density polyethylene (HDPE) storage bottles for reagent solutions and plastic items were acid cleaned following a standard procedure (Worsfold et al., 2005; Omaka, 2007). All items for collecting and storing samples and reagents were first washed with distilled water, soaked in a $10 \% \mathrm{HCl}$ solution for at least $24 \mathrm{~h}$ (Prior and Johnes, 2002) and rinsed three times with distilled water. The washed items were dried and stored in zip locked polyethylene bags.

Water samples were collected in these sterile, wide mouthed containers (ca. 1 litre) with cap. The containers were completely filled with water and capped to prevent spillage.

Tests on each sample were carried out upon return to the laboratory, within one hour of collection. However, $\mathrm{pH}$, temperature, dissolved oxygen, conductivity and turbidity were carried out in-situ at the sampling sites using probes (A pocket-sized $\mathrm{pH}$ meter pHep® $\mathrm{C} 175$ Hanna Instruments, Italy; LCD portable digital multi-stem thermometer with external probe (Model - ST -9269); Lutron DO5509 DO meter, Taiwan; A pocket-size conductivity meter Hanna Instruments, Italy).

\section{Analytical Procedures}

The physicochemical parameters determinations were carried out according to standard methods: Total Acidity was determined by titration (Duruibe et al., 2007), total alkalinity by acid titration using methyl-orange as an indicator (Arain et al., 2008), BOD by Winkler's method, and COD by dichromate method (Duruibe et al., 2007).

Nitrate and phosphate were determined spectrophotometrically at 410 and $820 \mathrm{~nm}$ respectively (Jenkins and Medsken, 1964; Omaka et al., 2007; Valderrama, 1981). The analytical method for the determination of phosphate was based on the formation of 12-molybdophosphoric acid from phosphate and molybdate in acid solution and subsequent reduction to a blue heteropoly compound. The Filterable Reactive Phosphorus (FRP) was analyzed after filtration of samples with 0.45 micron filter paper. The nitrate was based on the reaction of the nitrate ion with brucine sulphate in a $13 \mathrm{~N}$ $\mathrm{H}_{2} \mathrm{SO}_{4}$ solution at a temperature of $100{ }^{\circ} \mathrm{C}$. 


\section{Results and Discussion}

Ten (10) sites were sampled and analyzed viz: 1. Ebonyi River at Onuebonyi, 2. Ama River at Timbershade, 3. Seasonal Stream at Ezza Road, 4. Azuiyiokwu River at Afikpo Road, 5. Stream at Presco campus of Ebonyi State University, 6. Iyiudele River at Grace Court Hotels, 7. Iyiudele River at Waterworks Road, 8. Seasonal Stream at Oversea Hostel Presco campus of Ebonyi State University, 9. Azuiyiokwu River at Hope-High International School and 10. Azuiyiokwu River at Abakaliki-Ogoja Expressway. The sites are all in Abakaliki Capital of Ebonyi State. The samples were collected from May, 2011 to November, 2011. The results of the analysis are presented in tables 1 and 2.

The temperature of all the studied sites was ambient within the acceptable standards (Itumoh et al., 2011). Apart from the temperature of $29.17 \pm 2.02,29.33 \pm 2.31$ and $30.00 \pm 2.65$ observed in Ebonyi River at Onuebonyi, lyiudele River at Grace Court Hotels and Azuiyiokwu River at Abakaliki-Ogoja Expressway, the rest had temperatures ca. $28{ }^{\circ} \mathrm{C}$ healthy for the survival of aquatic plants and animals.

The $\mathrm{pH}$ of the samples were within the acceptable limits, according to WHO and National Agency for Food, Drug Administration and Control (NAFDAC), at $25^{\circ} \mathrm{C}$ (Arain et al., 2008; Duruibe et al., 2007). The slightly alkaline $\mathrm{pH}$ values for some sites could be due to the presence of carbonates and bicarbonates in the water (Murhekar, 2011). Also, the values of the $\mathrm{pH}$ are well preferred for aquatic and biological activities in water and this implies that there will be abundance of aquatic plants and animals at the sites. For the Seasonal Stream at Presco campus of Ebonyi State University and lyiudele River at Waterworks Road with $\mathrm{pH}$ values of $6.90 \pm 0.14$ and $6.8 \pm 0.35$ respectively, may have resulted from activities prevalent in this areas e.g., the washing of used fertilizer bags at the lyiudele River and waste discharges.

Within the temperature range of $(28.60-30.00)$, the \% Saturation of the water in all the sites was very low. The low \% Saturation, by implication, low DO could have resulted from high levels of bacteria activities or large amounts of rotting plants. This was also true because the temperature and $\mathrm{pH}$ conditions favour the activities of aquatic organisms. The DO values also reflected the levels of pollution at these sites (Murhekar, 2011). The Ama River at Timbershade $(1.43 \pm 0.15)$ and

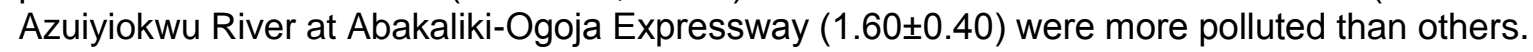

The turbidity varied between 41.00 to 97.67 NTU and was above the limits prescribed by WHO and Indian Standards Institution ISI (10500-91) (Murhekar, 2011). Although the results represented mean values $(n=7)$, the turbidity was less during the rainy seasons (May - August). Refuse disposal, urban runoff flowing into these water bodies, flood, and soil erosion affected the turbidity.

On the average of $28^{\circ} \mathrm{C}$, the electrical conductivity values of the water samples were far below the prescribed standard $\left(1400 \mu \mathrm{Sm}^{-1}\right.$ at $\left.28^{\circ} \mathrm{C}\right)$ (Murhekar, 2011). This simply means that samples contained fewer amounts of dissolved salts. The studied sites fall within tropical rainforest zone of West Africa with abundant precipitation (about $1500 \mathrm{~mm}$ on average).

The total acidity and alkalinity of the sites were within the prescribed limits. Alkalinity of 30 and 50 $\mathrm{mg} \mathrm{I}^{-1}$ are generally acceptable to fish and shrimp production (Lawson, 2011).

The BOD and COD results suggest possible pollution of the studied sites. The result of the COD (48.883 \pm 156.06$)$ from the Azuiyiokwu R. at Abakaliki-Ogoja Express Road is not surprising because there is a waste disposal site close to the banks of the River which may contributes to its pollution. This was similar to the River course at Hope-High International School. The lyiudele R. at Waterworks Road stood most polluted. This was reflected by the high phosphate concentration $\left(1.17 \pm 0.06 \mathrm{mg} \mathrm{l}^{-1}\right)$.

The results of the nutrient loads (nitrate and phosphate) were within prescribed limits. However, accumulation of the nutrients over time will eventually result in eutrophication. The washing of used fertilizer bags around the lyiudele R. at Waterworks Road resulted to the elevated concentrations of phosphate at the site. Agricultural activities (e.g. the use of phosphate and urea fertilizers) are the major contributory factors to the concentrations of the nutrients in the area.

The results from Ebonyi River were compared with the results obtained from other locations because other rivers and streams studied in this work discharge into it (Tables 3 and 4). 
Table 1. The mean results of the physicochemical analysis from the 10 studied sites compared to standards $( \pm$ SD) $(n=7)$

\begin{tabular}{|c|c|c|c|c|c|c|c|c|c|c|}
\hline \multicolumn{2}{|c|}{ Location } & $\begin{array}{c}\text { Temperature } \\
\left({ }^{\circ} \mathrm{C}\right)\end{array}$ & $\mathrm{pH}$ & $\begin{array}{c}\text { Dissolved } \\
\text { Oxygen } \\
\left(\mathrm{mg} \mathrm{l}^{-1}\right) \\
\end{array}$ & $\begin{array}{c}\text { Turbidity } \\
\text { (NTU) }\end{array}$ & $\begin{array}{l}\text { Conductivity } \\
\left(\mu \mathrm{S} \mathrm{cm}^{-1}\right)\end{array}$ & $\begin{array}{l}\text { Total acidity } \\
\left(\mathrm{mg} \mathrm{l}^{-1}\right)\end{array}$ & $\begin{array}{c}\text { Total } \\
\text { alkalinity } \\
\left(\mathrm{mg} \mathrm{l}^{-1}\right) \\
\end{array}$ & $\begin{array}{l}\text { BOD } \\
\left(\mathrm{mg} \mathrm{l}^{-1}\right)\end{array}$ & $\begin{array}{l}\text { COD } \\
\left(\mathrm{mg} \mathrm{l}^{-1}\right)\end{array}$ \\
\hline 1. & $\operatorname{Rv} 1$ & $29.17 \pm 2.02$ & $7.1 \pm 0.51$ & $2.5 \pm 0.95$ & $95.3 \pm 49.81$ & $80.0 \pm 7.00$ & $11.2 \pm 4.79$ & $7.63 \pm 1.52$ & $5.07 \pm 1.25$ & $33.443 \pm 180.01$ \\
\hline 2. & $R v 2$ & $29 \pm 1.87$ & $7.43 \pm 0.40$ & $1.43 \pm 0.15$ & $97.67 \pm 52.21$ & $19.00 \pm 1.01$ & $13.60 \pm 8.39$ & $8.23 \pm 2.29$ & $5.23 \pm 3.23$ & $43.400 \pm 250.14$ \\
\hline 3. & St 1 & $28.67 \pm 2.02$ & $6.73 \pm 0.75$ & $2.20 \pm 1.23$ & $97.33 \pm 51.86$ & $77.70 \pm 1.37$ & $10.10 \pm 5.63$ & $9.80 \pm 1.51$ & $3.23 \pm 1.00$ & $35.040 \pm 294.52$ \\
\hline 4. & $R v 3$ & $28.87 \pm 2.15$ & $7.63 \pm 0.29$ & $3.40 \pm 1.06$ & $62.67 \pm 48.35$ & $39.00 \pm 1.01$ & $13.07 \pm 1.90$ & $10.97 \pm 2.48$ & $4.40 \pm 1.22$ & $23.530 \pm 101.75$ \\
\hline 5. & St 2 & $28.87 \pm 1.53$ & $6.90 \pm 0.14$ & $2.37 \pm 1.62$ & $57.67 \pm 4.64$ & $56.70 \pm 3.01$ & $11.03 \pm 1.83$ & $10.47 \pm 2.19$ & $6.07 \pm 0.99$ & $16.200 \pm 43.73$ \\
\hline 6. & $\operatorname{Rv} 4$ & $29.33 \pm 2.31$ & $7.93 \pm 0.12$ & $3.30 \pm 2.46$ & $43.00 \pm 18.68$ & $113.30 \pm 4.04$ & $14.63 \pm 9.12$ & $8.73 \pm 4.05$ & $1.20 \pm 0.17$ & $39.266 \pm 439.59$ \\
\hline 7. & Rv 5 & $28.80 \pm 1.92$ & $6.8 \pm 0.35$ & $2.6 \pm 2.60$ & $83.33 \pm 58.53$ & $130.00 \pm 4.00$ & $17.23 \pm 10.42$ & $6.43 \pm 2.00$ & $1.77 \pm 1.24$ & $53.533 \pm 581.01$ \\
\hline 8. & St 3 & $28.60 \pm 2.16$ & $7.63 \pm 0.29$ & $3.23 \pm 3.10$ & $41.00 \pm 13.08$ & $80.00 \pm 2.65$ & $9.67 \pm 4.93$ & $8.20 \pm 1.14$ & $3.93 \pm 1.59$ & $36.637 \pm 16.37$ \\
\hline 9. & $\operatorname{Rv} 6$ & $28.60 \pm 2.16$ & $7.50 \pm 0.70$ & $3.53 \pm 3.11$ & $3.53 \pm 32.55$ & $613.30 \pm 7.77$ & $10.67 \pm 3.66$ & $9.17 \pm 2.50$ & $7.03 \pm 5.64$ & $43.981 \pm 181.79$ \\
\hline 10. & $\operatorname{Rv} 7$ & $30.00 \pm 2.65$ & $7.93 \pm 0.12$ & $1.60 \pm 0.40$ & $41.33 \pm 1.15$ & $163.30 \pm 0.58$ & $13.83 \pm 8.00$ & $7.63 \pm 1.64$ & $5.10 \pm 2.71$ & $48.883 \pm 156.06$ \\
\hline \multicolumn{2}{|c|}{ Standards } & Ambient $^{\mathrm{a}}$ & $6.5-8.5^{\mathrm{D}}$ & - & $5.0^{\mathrm{C}}$ & $1400^{c}$ & $100.0^{d}$ & $100.0^{d}$ & $3.0^{\mathrm{d}}$ & $294.0^{d}$ \\
\hline
\end{tabular}

1. Ebonyi River at Onuebonyi, 2. Ama River at Timbershade, 3. Seasonal Stream at Ezza Road, 4. Azuiyiokwu River at Afikpo Road, 5. Seasonal Stream at Presco campus of Ebonyi State University, 6. Iyiudele River at Grace Court Hotels, 7. lyiudele River at Waterworks Road, 8. Seasonal Stream at Oversea Hostel Presco campus of Ebonyi State University, 9. Azuiyiokwu River at Hope-High International School and 10. Azuiyiokwu River at Abakaliki-Ogoja Expressway. (Rv = River, $\mathrm{St}=$ Seasonal Stream, NTU = nephelometric turbidity unit).

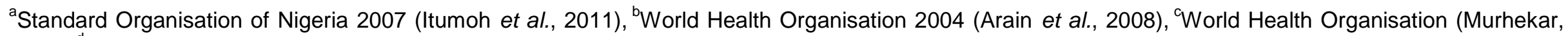
2011), ${ }^{\mathrm{d}}$ National Agency for Food, Drug Administration and Control (Duruibe et al., 2007). 
Table 2. The mean concentrations of nutrient loads of 10 studied sites compared to standards $( \pm \%$ RSD $)(n=7)$

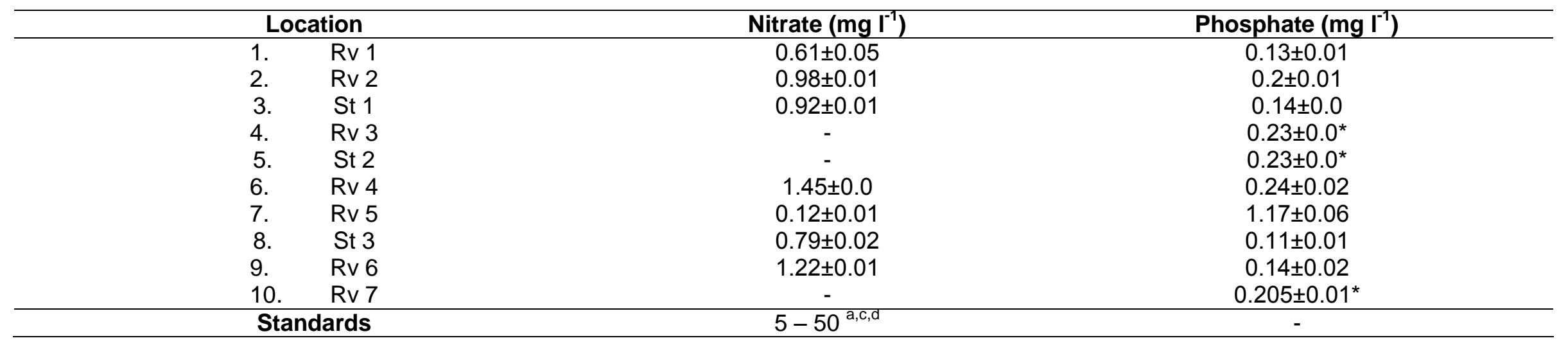

1. Ebonyi River at Onuebonyi, 2. Ama River at Timbershade, 3. Seasonal Stream at Ezza Road, 4. Azuiyiokwu River at Afikpo Road, 5. Seasonal Stream at Presco campus of Ebonyi State University, 6. Iyiudele River at Grace Court Hotels, 7. lyiudele River at Waterworks Road, 8. Seasonal Stream at Oversea Hostel Presco campus of Ebonyi State University, 9. Azuiyiokwu River at Hope-High International School and 10. Azuiyiokwu River at Abakaliki-Ogoja Expressway. $(\mathrm{Rv}=\mathrm{River}, \mathrm{St}=$ Seasonal Stream)

* Fiterable Reactive Phosphorus (FRP)

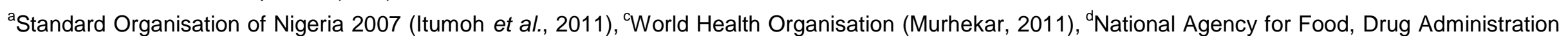
and Control (Duruibe et al., 2007). 
Table 3. The mean range values of physicochemical parameters of studied site and comparison with other published values

\begin{tabular}{|c|c|c|c|c|c|c|c|c|c|}
\hline Location (authors) & $\begin{array}{c}\text { Temperature } \\
\left({ }^{\circ} \mathrm{C}\right)\end{array}$ & pH & $\begin{array}{c}\text { DO } \\
\left(\mathrm{mg} \mathrm{l}^{-1}\right)\end{array}$ & $\begin{array}{l}\text { Turbidity } \\
\text { (NTU) }\end{array}$ & $\begin{array}{l}\text { Conductivity } \\
\left(\mu \mathrm{cm}^{-1}\right)\end{array}$ & $\begin{array}{l}\text { T. acidity } \\
\left(\mathrm{mg} \mathrm{l}^{-1}\right)\end{array}$ & $\begin{array}{l}\text { T. alkalinity } \\
\left(\mathrm{mg} \mathrm{l}^{-1}\right)\end{array}$ & $\begin{array}{c}\text { BOD } \\
\left(\mathrm{mg} \mathrm{l}^{-1}\right)\end{array}$ & $\begin{array}{l}\text { COD } \\
\left(\mathrm{mg} \mathrm{l}^{-1}\right)\end{array}$ \\
\hline Standards & Ambient $^{\mathrm{a}}$ & $6.5-8.5^{b}$ & - & $5.0^{\mathrm{C}}$ & $1400^{\mathrm{C}}$ & $100.0^{\mathrm{d}}$ & $100.0^{d}$ & $3.0^{\mathrm{d}}$ & $294.0^{d}$ \\
\hline $\begin{array}{l}\text { Ebonyi River Abakaliki, } \\
\text { Nigeria (This work) }\end{array}$ & $29.17 \pm 2.02$ & $7.13 \pm 0.51$ & $2.53 \pm 0.95$ & $95.33 \pm 49.81$ & $80.00 \pm 7.00$ & $11.20 \pm 4.79$ & $7.63 \pm 1.52$ & $5.07 \pm 1.25$ & $33.443 \pm 180.0$ \\
\hline $\begin{array}{l}\text { Mangrove Swamp of } \\
\text { (UNILAG) Lagos, Nigeria } \\
\text { (Lawson, 2011) }\end{array}$ & $28.35 \pm 1.75$ & $7.03 \pm 1.83$ & $4.95 \pm 3.15$ & - & - & $16.36 \pm 4.28$ & $43.33 \pm 18.60$ & - & - \\
\hline $\begin{array}{c}\text { Manchar Lake Water Pakistan } \\
\text { (Arain et al., 2008) }\end{array}$ & - & $8.02 \pm 0.21$ & - & - & $5243 \pm 1786$ & - & $157.0 \pm 40.3$ & - & - \\
\hline $\begin{array}{c}\text { Diamond Food Effluents, } \\
\text { Ibadan, Nigeria (Adebisi and } \\
\text { Fayemiwo, 2010) }\end{array}$ & - & $9.10 \pm 0.26$ & $7.50 \pm 0.22$ & $35.21 \pm 1.02$ & $12.00 \pm 0.35$ & - & - & $41.00 \pm 18.18$ & $52.00 \pm 1.50$ \\
\hline $\begin{array}{l}\text { Ona River Ondo State, } \\
\text { Nigeria (Adefemi and } \\
\text { Awokunmi, 2010) }\end{array}$ & $27.10 \pm 1.61$ & $7.45 \pm 0.35$ & - & - & $1150 \pm 252.66$ & - & $2.45 \pm 0.51$ & - & - \\
\hline $\begin{array}{l}\text { Shiv Mandir River Akot City } \\
\text { India (Murhekar, 2011) }\end{array}$ & 29.00 & 9.50 & 7.20 & 12.00 & 1590.00 & - & 370.00 & - & - \\
\hline $\begin{array}{l}\text { Ekpan River ,Warri Nigeria } \\
\text { (Nduka et al., 2008) }\end{array}$ & - & 6.80 & 4.40 & 40.40 & - & - & - & - & 15.00 \\
\hline $\begin{array}{c}\text { Lagos Lagoon, Nigeria } \\
\text { (Ladipo et al., 2012) }\end{array}$ & - & $6.99 \pm 0.36$ & $4.98 \pm 1.08$ & $6.57 \pm 6.46$ & $\begin{array}{c}18904.59 \pm 535 \\
3.64 \\
\end{array}$ & - & $84.97 \pm 16.53$ & $13.04 \pm 7.46$ & $78.12 \pm 49.14$ \\
\hline $\begin{array}{c}\text { Akinyele River, Ibadan } \\
\text { City,Nigeria (Adeyemo et al. } \\
\text { 2008) }\end{array}$ & - & 7.00 & 0.40 & - & - & - & - & - & 31.00 \\
\hline $\begin{array}{c}\text { Ivo River Ebonyi State Nigeria } \\
\text { (Abara et al., 2005) }\end{array}$ & 7.3 & 27.6 & 5.7 & 30.5 & 95.2 & - & - & - & - \\
\hline
\end{tabular}

T. acidity $=$ Total acidity, $T$. alkalinity $=$ Total alkalinity

${ }^{a}$ Standard Organisation of Nigeria 2007 (Itumoh et al., 2011), ${ }^{b}$ World Health Organisation 2004 (Arain et al., 2008), World Health Organisation (Murhekar, 2011), ${ }^{d}$ National Agency for Food, Drug Administration and Control (Duruibe et al., 2007). 
Table 4. Mean range of values for nutrient loads of studied site and comparison with other published values Location (authors)

Nitrate $\left(\mathrm{mg} \mathrm{l}^{-1}\right)$

$$
5-50^{2}
$$

Ebonyi River Abakaliki, Nigeria (This work)

Manchar Lake Water Pakistan (Arain et al., 2008)

Akinyele River Ibadan City, Nigeria (Adeyemo et al., 2008).

Lagos Lagoon Nigeria (Ladipo et al., 2012)

Ekpan River Warri Nigeria (Nduka et al., 2008)

$$
0.61 \pm 0.05
$$

-

$4.86 \pm 1.59$
Phosphate ( $\left.\mathrm{mg} \mathrm{I}^{-1}\right)$ -

$0.13 \pm 0.01$

$0.44 \pm 0.14$

16.00

$9.75 \pm 3.24$ 1.14

${ }^{a}$ Standard Organisation of Nigeria 2007 (Itumoh et al., 2011), 'World Health Organisation (Murhekar, 2011), 'National Agency for Food, Drug Administration and Control (Duruibe et al., 2007). 
The results also compared closely with the results reported in another work done in the same area (Abara et al., 2005). However, the conductivity value was far compared with others especially that obtained from Lagos Lagoon (18904.59 \pm 5353.64$)$ (Ladipo et al., 2012). Except the DO report from Akinyele R. (Adeyemo et al., 2008), the other results were relatively higher compared with the data on Table 1, which suggest low level of bacteria activities. The COD value compares relatively to all other values, while the BOD was comparatively less, although the BOD values were all above the standard. Except the Lagos Lagoon with higher nitrate $(4.86 \pm 1.59)$ and phosphate $(9.75 \pm 3.24)$ concentrations and the Akinyele R., with phosphate (16.00) concentration, the other values compared well.

\section{CONCLUSION}

Physicochemical parameters and nutrient loads studies of the rivers and streams in Abakaliki, Ebonyi State suggest that refuse disposal, fertilizer use, soil erosion and flooding, etc. contributed in various ways to the impairment of the water quality of the studied sites. Of all parameters investigated, the turbidity (NTU) and BOD ( $\left.\mathrm{mg} \mathrm{I}^{-1}\right)$ were well above the prescribed standards. Although the results do not indicate adverse pollution status of any of the studied sites, they provided the need for further studies and monitoring.

\section{ACKNOWLEDGEMENT}

The authors are very thankful to the Department of Industrial Chemistry, Ebonyi State University for their support and provision of laboratory space for this study.

\section{REFERENCES}

Abara P.N., Obiekezie S.O., Onyeagba R.A. and Nwaugo V.O. (2005), Physicochemical Characteristics of Ivo River, Ebonyi State Nigeria, International Journal of Natural Sciences, 1(2), 145-149.

Adebisi S.A. and Fayemiwo K.A. (2010), Physiochemical Properties of Industrial Effluents in Ibadan, Nigeria, Nature and Science 8(12), 234-238.

Adefemi S.O. and Awokunmi E.E. (2010), Determination of Physico-Chemical Parameters and Heavy Metals in Water Samples from Itaogbolu Area of Ondo-State, Nigeria, African Journal of Environmental Science and Technology, 4(3), 145-148.

Adeyemo O.K., Adedokun O.A., Yusuf R.K. and Adeleye E.A. (2008), Seasonal Changes in Physicochemical Parameters and Nutrient Load of River Sediments in Ibadan city, Nigeria, Global NEST Journal, 10(3), 326-336.

Arain M.B., Kazi T.G., Jamali M.K., Afridi H.I., Baig J.A., Jalbani N. and Shah A.Q. (2008), Evaluation of Physico-Chemical Parameters of Manchar Lake Water and Their Comparison with Other Global Published Values, Pak. J. Anal. Environ. Chem., 9(2), 101 - 109.

Bellingham K. (2012), Physicochemical Parameters of Natural Waters. Stevens Water Monitoring Systems, Inc. (accessed on 20/07/2012 from http://www.stevenswater.com)

Collins-Longman (1981), New Secondary Atlas (Rev. ed.). Sheck-Wah Tong Printing Press Ltd., Hong Kong.

Duruibe J.O., Ogwuegbu M.O.C. and Egwurugwu J.N. (2007), Pollution Profiles of Non-metallic Inorganic and Organic Pollutants of Drinking and Potable Waters due to Mining Activities in Ishiagu (Ebonyi State) of Nigeria, International Journal of Physical Sciences, 2(8), 202-206.

Ezeh H. and Ugwu S. (2007), Geo-electric Investigation of Sulphide Mineralization at Egu-Echaraunuhu, Abakaliki, S.E. Nigeria, J. Applied Natural Sciences, 1(1), 59-63.

Halliwell D.J., McKelvie I.D., Hart B.T. and Dunhill R.H. (1996), Separation and Detection of Condensed Phosphates in Waste Waters by Ion Chromatography Coupled with Flow Injection, Analyst, 121, 1089-1093.

Itumoh E.J., Izuagie T., Omaka N.O., Uba A., Shuaibu M., Dogonyaro I.A., Isah A., Dange A.U. and Isah S.I. (2011), Trace Metals Analysis of Soil and Water Samples from a Limestone Mining Site in Sokoto State Nigeria, Journal of Physical Sciences and Innovation, 3, 62-71.

Jenkins D. and Medsken L. (1964), A Brucine Method for the Determination of Nitrate in Ocean, Estuarine, and Fresh Waters, Analytical Chemistry, 36, 610. 
Ladipo M.K., Ajibola V.O. and Oniye S.J. (2012), Apllication of Multivariate Statistical Methods to Assessment of Water Quality in Selected Locations of Lagos Lagoon, Nigeria, Environmental Research Journal, 6(3), 141-150.

Lawson E.O. (2011), Physico-Chemical Parameters and Heavy Metal Contents of Water from the Mangrove Swamps of Lagos Lagoon, Lagos, Nigeria, Advances in Biological Research, 5(1), 8-21.

Monteiro M.I.C., Ferreira F.N., de Oliveira N.M.M and Ávila A.K. (2003), Simplified Version of Sodium Salicylate Method for Analysis of Nitrate in Drinking Waters, Analytica Chimica Acta, 477, 125-129.

Murhekar G.H. (2011), Determination of Physico-Chemical Parameters of Surface Water Samples in and around Akot City, International Journal of Research in Chemistry and Environment, 1(2), 183-187.

Nduka J.K., Orisakwe O.E. and Ezenweke L.O. (2008), Some Physicochemical Parameters of Potable Water Supply in Warri, Niger Delta Area of Nigeria, Scientific Research and Essay, 3(11), 547-551.

Omaka O.N. (2007), Phosphorus in the Environment, Effects of Eutrophication, Cycle, Fractionation, Determination and Procedures for Sampling and Storage - A Review, Journal of Applied and Natural Sciences, 1(1), 27-36.

Omaka O.N., Igidi J.O., Nwabue F.I. and Itumoh E.J. (2011), The Impacts of Oil Spill and Soil Factors on Trace Metals in Sediments (Soils) of Abakaliki and Afikpo, Nigeria, Journal of Emerging Trends in Engineering and Applied Sciences (JETEAS), 2(4), 648-657.

Omaka O.N., Keith-Roach M.J. and Worsford P.J. (2007), Flow Injection Spectrophotometric Method for the Determination of Filterable Reactive Phosphorus (FRP) in Natural Water in the Presence of High Concentration of Arsenate and Silicate, J. Chemical Society of Nigeria, 32(1), 143-149.

Prior H. and Johnes P.J. (2002), Regulation of Surface Water Quality in a Cretaceous Chalk Catchment, UK: an Assessment of the Relative Importance of Instream and Wetland Processes, The Science of the Total Environment, 282-283, 159-174.

Valderrama J.C. (1981), The Simultaneous Analysis of Total Nitrogen and Total Phosphorus in Natural Waters, Marine Chemistry, 10, 109-122.

WHO (2011), Guidelines for Drinking-Water Quality, 4th ed. World Health Organisation, Geneva, Switzerland.

Withers P.J.A and Lord E.I. (2002), Agricultural Nutrients Inputs to Rivers and Groundwaters in the UK: Policy, Environmental Management and Research Needs, The Science of the Total Environment, 282-283, 9-24.

Worsfold P.J., Omaka O.N., Gimbert L.J., Mankasingh U., Gardolinski P.C.F., Haygarth P.M., Turner B.L., Keith-Roach M.J. and McKelvie I.D. (2005), Sampling Protocols and Storage Parameters in the Analysis of Phosphorus and Nitrate Samples in Natural Waters, Talanta, 66, 273.

Zanin L., Robertson W.D., Ptacek C.J. and Schiff S.L. (1998), Phosphorus Characterization in Sediments Impacted by Septic Effluent at Four Sites in Central Canada, Journal of Contaminant Hydrology, 33, 405-429.

Zatar N.A.; Abu-Eid M.A. and Eid A.F. (1999), Spectrophotometric Determination of Nitrite and Nitrate Using Phosphomolybdenum Blue Complex, Talanta, 50, 819-826. 